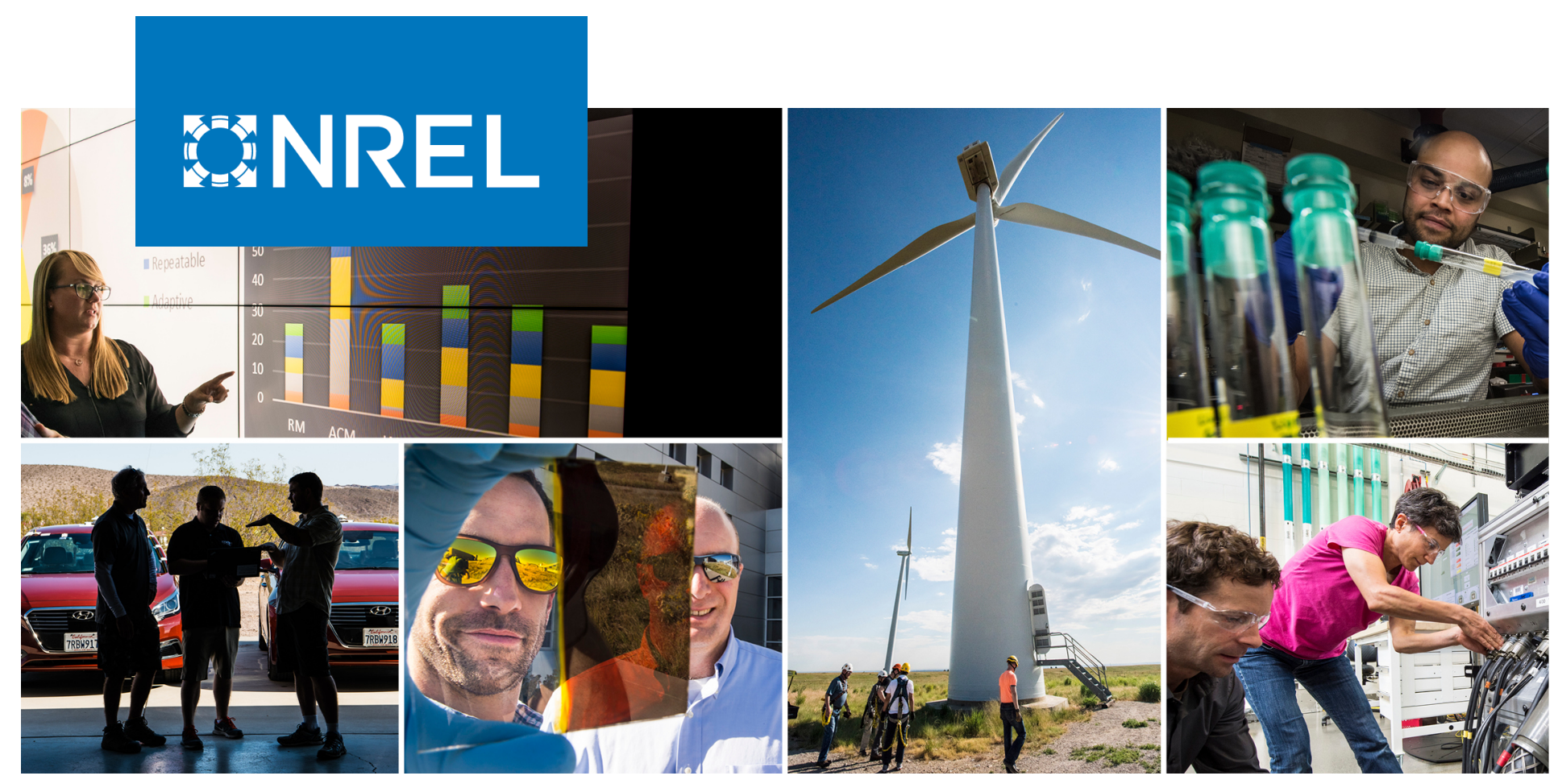

\title{
Insurance in the Operation of Photovoltaic Plants
}

Amy Schwab, Andy Walker, and Jal Desai

National Renewable Energy Laboratory

NREL is a national laboratory of the U.S. Department of Energy

Office of Energy Efficiency \& Renewable Energy

Operated by the Alliance for Sustainable Energy, LLC

This report is available at no cost from the National Renewable Energy Laboratory (NREL) at www.nrel.gov/publications.
Technical Report

NREL/TP-6A20-78588

December 2020 


\title{
GNREL
}

\section{Insurance in the Operation of Photovoltaic Plants}

\author{
Amy Schwab, Andy Walker, and Jal Desai
}

National Renewable Energy Laboratory

\section{Suggested Citation}

Schwab, Amy, Andy Walker, and Jal Desai. 2020. Insurance in the Operation of Photovoltaic Plants. Golden, CO: National Renewable Energy Laboratory.

NREL/TP-6A20-78588. https://www.nrel.gov/docs/fy21osti/78588.pdf.

NREL is a national laboratory of the U.S. Department of Energy Office of Energy Efficiency \& Renewable Energy Operated by the Alliance for Sustainable Energy, LLC

This report is available at no cost from the National Renewable Energy Laboratory (NREL) at www.nrel.gov/publications.

Contract No. DE-AC36-08GO28308
Technical Report NREL/TP-6A20-78588

December 2020

National Renewable Energy Laboratory 15013 Denver West Parkway Golden, CO 80401 303-275-3000 • www.nrel.gov 


\section{NOTICE}

This work was authored by the National Renewable Energy Laboratory, operated by Alliance for Sustainable Energy, LLC, for the U.S. Department of Energy (DOE) under Contract No. DE-AC36-08GO28308. Funding provided by U.S. Department of Energy Office of Energy Efficiency and Renewable Energy Solar Energy Technologies Office under agreement 34172. The views expressed herein do not necessarily represent the views of the DOE or the U.S. Government.

This report is available at no cost from the National Renewable Energy Laboratory (NREL) at www.nrel.gov/publications.

U.S. Department of Energy (DOE) reports produced after 1991 and a growing number of pre-1991 documents are available free via www.OSTI.gov.

Cover Photos by Dennis Schroeder: (clockwise, left to right) NREL 51934, NREL 45897, NREL 42160, NREL 45891, NREL 48097, NREL 46526.

NREL prints on paper that contains recycled content. 


\section{Preface}

This paper provides an overview of property and casualty insurance industry functions, insurance terminology descriptions, and special insurance coverage considerations for photovoltaic (PV) system owners, asset managers, operators, PV operation-and-maintenance service providers, utilities, and other parties. The paper includes the results of an analysis of 6 years of property and casualty insurance claims for PV equipment and discusses considerations for purchasing property and casualty insurance for owners and operators of PV systems. PV is a relatively new asset type, and insurance companies are revisiting rates and offerings as actuarial data become available. This paper seeks to inform decisions that optimize the balance of the cost of insurance with enabling benefits to finance, permitting and utility connections, and the operation of PV plants. 


\section{Acknowledgments}

Much information in this report was provided by coauthor Amy Schwab, a veteran of the property and casualty insurance industry. Her insurance company experience includes actuarial rate analysis, underwriting, strategic marketing, and operations improvement. Schwab achieved the Chartered Property Casualty Underwriter designation from the Insurance Institute of America in 1989. 


\section{Executive Summary}

A major component of operation-and-maintenance costs for commercial or utility-scale photovoltaic (PV) systems is insuring against losses from physical damage or liability for losses caused to others (Speer, Mendelsohn, and Cory 2010). This report focuses on helping PV system owners, operators, and related third parties understand the types, relative sizes, and variety of losses and identify the cost-effective risk mitigation strategies that balance insurance coverage costs while considering other risk management strategies. Understanding how insurance works and the roles of the various parties in the insurance transaction can help system owners and operators navigate buying decisions and get the most benefit from available resources. Finally, understanding the types of coverage and considerations in setting coverage limits, deductibles, and other key insurance parameters and understanding how those might apply differently to different types of PV systems - residential, commercial, utility-scale, and third parties - can help ensure adequate coverage at the best price. 


\section{Table of Contents}

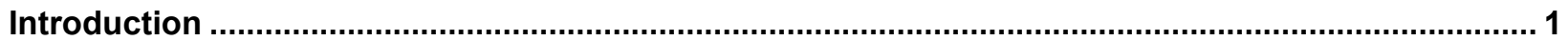

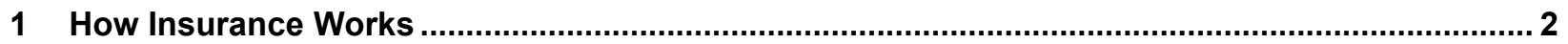

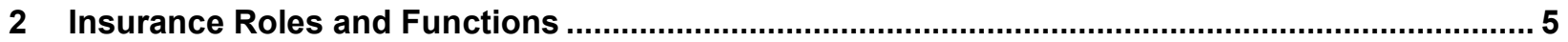

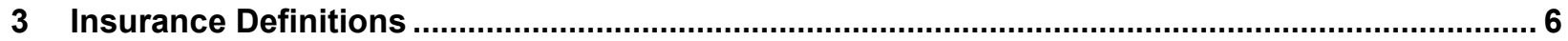

4 Types of Losses Involving Photovoltaic Equipment .......................................................... 9

5 Purchasing Insurance Coverage for Photovoltaic Systems …................................................... 17

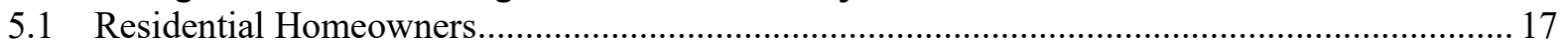

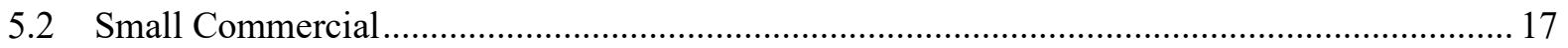

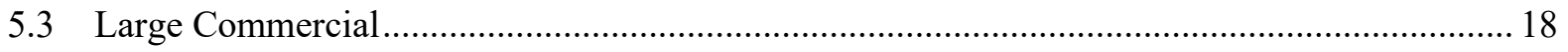

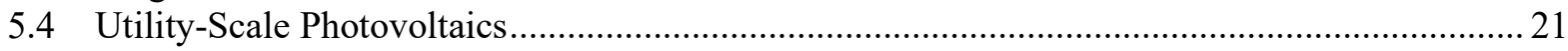

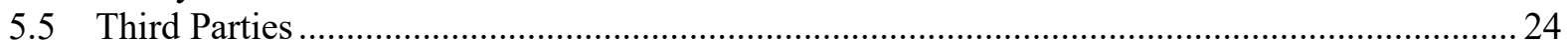

5.5.1 Consultants, Designers, Engineers, and Installers............................................... 24

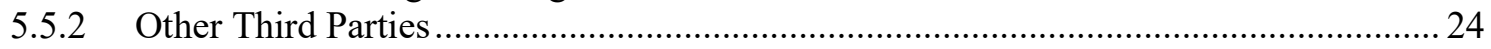

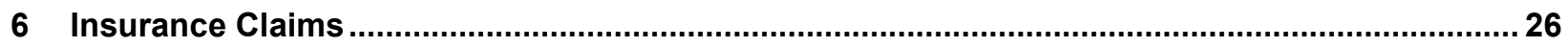

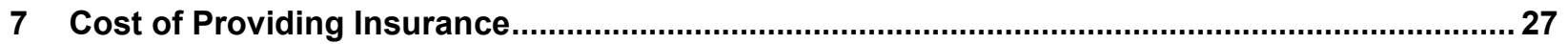

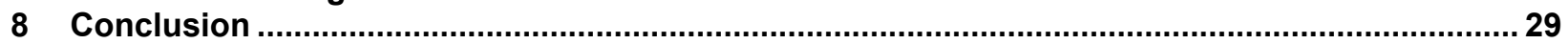

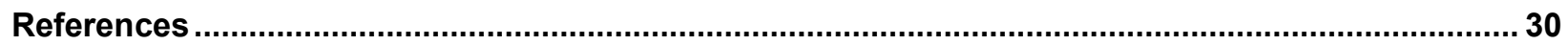




\section{List of Figures}

Figure 1. Average claim and average solar claim value across residential........................................... 10

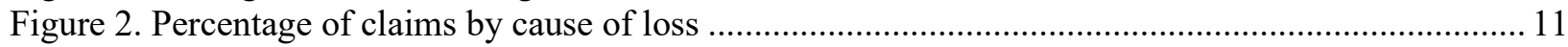

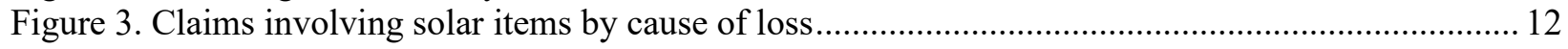

Figure 4. Colorado and Texas had the largest concentration of hail-related solar equipment losses. ........ 13

Figure 5. Wind-related losses were concentrated in Florida................................................................ 14

Figure 6. California had the largest concentration of fire-related solar equipment losses........................ 15

\section{List of Tables}

Table 1. Average Claim Value (\$) of Solar Items by Cause of Loss.................................................... 12

Table 2. Statistics on Solar Item Losses by Type ........................................................................ 16

Table 3. Insurance Requirements from Requests for Proposals for Commercial-Scale PV Systems......... 20

Table 4. Insurance Requirements from Requests for Proposals for Utility-Scale PV Systems ................. 23 


\section{Introduction}

Insurance is important to several aspects of photovoltaic (PV) plant operations. Insurance is often a prerequisite for financing, operating permits, interconnection agreements, and leases or as part of a power purchase agreement for an on-site PV system. The history of insurance for PV systems is short compared to other types of assets. Property and casualty insurers have been providing coverage for risks for centuries - the first fire insurance policies had their origins in the Great Fire of London in 1666 (Insurance Information Institute 2020b). Although coverage and practices for most property and casualty exposures are based on long histories and a great deal of data, insurance coverage for PV plants does not have the same amount of historical information and actuarial data. Coverage for new exposures, such as those specific to PV plants, evolves over time from specialty coverage provided by nonstandard markets into more standard market products as the technology matures. This paper provides context for PV plant operators to understand the influences impacting the availability and costs of insurance coverage, to consider the trade-offs in the purchasing decision, and to provide recommendations to help reduce the cost of insurance while also reducing overall risks and improving operations. In particular, this report provides an analysis of the causes of loss that involve PV equipment as well as an overview of the special coverage considerations for PV system owners, operators, and third parties. 


\section{How Insurance Works}

Insurance is one means of managing the risk of financial loss. It operates by transferring the financial risk of a loss to an insurance company through a contract (an insurance policy) that obligates the insurance company to pay or reimburse the PV plant owner, operator, or asset manager that purchases insurance (the policyholder or insured) against losses from covered events. The amounts paid for this coverage, called premiums, are determined by insurance company underwriters based on the types and characteristics of loss exposures covered under the policy. Exposures are the types of property or operations that could suffer or give rise to losses. Insurance companies (also called insurers) operate by charging each insured a relatively small amount based on the statistical probability of any one of a very large number of insureds experiencing a covered loss. By pooling premiums and exposures across a large number of policyholders, and perhaps by excluding certain exposures from coverage, insurers can spread the risk of expected losses to an acceptable cost for each individual policyholder, accumulate adequate premiums to pay the claims for losses that do occur, and realize an acceptable profit.

Based on historical data on the frequency and severity (size) of losses for different classes of exposures, insurance company actuaries calculate premium rates required to pay expected future claims. Insurance actuaries and underwriters first classify exposures based on the type of insured - either personal or commercial - and they may write coverage for only one of these areas. Personal lines insurance covers individuals and households through, for example, homeowners' insurance that would cover a residential PV system. Exposures not categorized as personal lines are classified as commercial. Commercial lines insurers further classify insureds into groups such as small business or major markets, or they can be based on a specific industry, such as PV plants or by the type of loss exposure.

The second major distinction is between property and casualty (also called liability) exposures. Property coverage protects the insured against financial losses to owned property, whereas casualty coverage protects the insured against financial losses to others that arise from the insured's premises, operations, or actions for which the insured is legally liable. For example, property insurance covers damage to a homeowner's rooftop PV system or to a utility-scale system from a weather event, such as hail, wind, lightning, or snow; whereas casualty coverage insures against the liability to others for loss resulting from insured's property or operation. Casualty insurance protects against liability for bodily injury or property damage to others, for example, caused by the PV system, such as by wind-liberated solar panels or fire caused by a problem with the PV system. By understanding the historical frequency and severity of losses across many similar exposures across many years, insurers estimate the future frequency and severity of expected claims from various causes. They are also able to quantify factors that either increase or decrease the probability or size of the loss. When exposures are well known and based on a long and stable history of losses, insurers can accurately estimate the causes, frequency, and severity of losses. This allows them to determine insurance rates adequate to pay all actual losses and retain a fair profit in return for assuming the risk that losses could exceed estimates. These pooled premiums are invested until needed to pay claims.

Insurance company underwriters evaluate a proposed insurance buyer's exposure to loss and design insurance policies with premium levels intended to provide adequate coverage for the buyer while compensating the insurance company in case actual losses exceed projections. When 
an insurance buyer has exposures that are outside an underwriter's experience or pose a higher probability of loss than the underwriter is willing to accept, the insurer could decline to cover those particular exposures, or they could decline to offer any coverage at all. As underwriters gain more experience with a set of exposures (such as exposures specific to PV systems), they can more accurately price coverage. For example, insurance companies might learn that PV systems are particularly susceptible to hail or wind but experience less damage due to heavy rain than other asset classes. They can also better identify prospective insureds with favorable characteristics and lower loss exposures, and they can incentivize insureds to take actions to reduce the likelihood or the size of losses, thus reducing premiums and corresponding losses and improving profitability.

Insurance company operations are regulated by state insurance commissioners. Aspects of insurance operations subject to regulation include policy language and rates to ensure that coverage and premiums being charged are fair and adequate and that loss reserves will be adequate. They also regulate the type of investments allowed to ensure that companies will be able to pay future claims as promised. ${ }^{1}$

In a nascent and rapidly growing market such as PV plant operations, or during periods of strong investment returns and stable losses, insurance companies compete for policyholders. This can enable insurance buyers to negotiate more favorable insurance terms, such as premium reductions, and coverage expansions. Over time, if the total pool of premiums collected is not enough to cover actual losses paid out, or when investment returns fall, insurance companies need to request rate increases to regain profitability. In extreme cases - especially with new technologies or new insurance coverage with limited historical loss experience - initial estimates can vary significantly from actual losses. If actual losses over time are less than estimates, insurance companies reduce rates and premiums to remain competitive. If actual losses exceed estimated losses, this can result in reductions in coverage or large premium increases - as much as doubledigit or triple-digit percentage increases from previous periods. This can affect the availability of coverage for PV plants until rates are readjusted.

When insurers are unable to get approval for rate increases adequate to offset losses, they might stop providing unprofitable coverage in a state. As companies pull out of markets, the reduced competition can leave few options for insurance buyers other than to pay increased premiums and/or to reduce their coverage even though loss exposures might not have changed. Insurance contracts are typically written on an annual basis, so this annual premium volatility can be a challenge for utility-scale PV system operators that might be unable to pass along increased insurance costs in their contracted power purchase price.

As newer technologies such as PV systems mature over time, and as system owners, operators, and insurers gain historical experience and increased data, improvements are identified that can reduce the frequency and severity of losses. This allows insurance companies to rebalance rates compared with losses, more accurately price policies, and more knowledgably provide coverage.

\footnotetext{
${ }^{1}$ A list of state insurance commissioners is maintained by the National Association of Insurance Commissioners at https://content.naic.org/state web map.htm.
} 
Although most attention in the insurance transaction is focused on the premium and coverage negotiation, two other insurance company functions are also very important, especially for commercial policyholders: claims handling and risk engineering. Claims handling can be critical in helping to reestablish full operations following a loss. Insurance companies that specialize in the PV industry often have expert claims handlers that can help minimize system downtime and ensure identification of less obvious losses. Claims-paying ability and claims-handling responsiveness are as important as low premium rates. Some insurance companies might compete aggressively on premiums, but when claims inevitably occur, they could be slow to respond or could even become adversarial. Other insurers might not offer the lowest premiums but might have strong reputations for being responsive when claims arise.

Specialty insurers with extensive experience with similar types of insurance buyers, exposures, and claims often maintain specialized risk engineering functions that help insureds better manage loss exposures and reduce their potential for loss. Loss control specialists can help policyholders prevent losses and minimize downtime and/or costs when a loss occurs. Specialty insurers share the knowledge and expertise they gain in a particular area with their policyholders. This can extend beyond reducing insured loss exposures to include tips on improving overall operations, providing guidance on state-of-the-art best practices, and reducing other costs.

Given that the insurance buyer is purchasing a promise of a future payment, if a loss occurs, the financial strength of the insurance company is important. A low premium is not meaningful if the company is unable or unwilling to honor its promise later when the business depends on prompt and effective claims handling. Although insurance companies are regulated by the states where they do business, not all insurance companies are equally strong financially. States set minimum standards, but companies often have vastly different risk appetites, as reflected by loss reserve, investment practices, and market competitiveness. "Five independent agencies-A.M. Best, Fitch, Kroll Bond Rating Agency, Moody's and Standard \& Poor's - rate the financial strength of insurance companies" (Insurance Information Institute 2020a). The rating schemas for each agency differ, and each periodically reevaluates insurance company ratings. 


\section{Insurance Roles and Functions}

Unlike many other financial contracts, insurance companies are generally accessed through insurance agents or brokers. Agents and brokers serve similar functions in the insurance transaction. As the middle person between the insurance buyer and the insurance company, however, agents and brokers differ in whose interests they represent. Agents work on behalf of one or several insurance companies, seeking clients who will purchase insurance. Brokers, on the other hand, represent the insurance buyer and seek insurance companies that will meet their client's needs. Personal lines and small commercial coverage are typically handled through insurance agents. More complex and larger buyers often turn to specialty agents or brokers who work with one or more insurance companies with special expertise in insuring specific types of businesses, such as technology or renewable energy generation. Brokers, as representatives of the insurance buyer, might also serve as risk managers, guiding buyers through the entire risk management process of inventorying and assessing risks and exposures and evaluating a variety of risk mitigation, financing, or management alternatives - including insurance coverage. For new types of loss exposures, such as new technologies or new applications of technologies, or for complex exposures, specialty brokers can access nonstandard markets (also called excess, or surplus lines markets). Companies in these markets are regulated differently and provide coverage designed for more unique exposures.

Although brokers might serve in a risk management role, insurance buyers with large and/or complex risks often employ in-house risk management staff or engage a risk management consultant to ensure that all risks are adequately identified, quantified, and cost-effectively addressed. Risk managers typically have relationships with multiple brokers and agents and are up to date on current insurance market dynamics. This enables them to design or negotiate innovative insurance solutions. Brokers or risk management firms might also enable large insurance buyers to access reinsurers or excess insurance markets. Reinsurers typically provide reinsurance coverage to insurance companies to cap the primary insurance company's aggregate losses in exchange for a share of the premiums the insurance company has collected. For large commercial insurance buyers - especially operators of fleets of PV systems with multiple locations that provide a geographic spread of exposure - reinsurers can provide excess-of-loss coverage. This means that the insured retains losses up to a high deductible, funding predictable losses from operations or from a self-insurance fund. The reinsurer pays only when losses exceed a given, often large, threshold deductible amount. Such large buyers often retain risk management consultants to help determine the appropriate trade-offs between the cost of insurance premiums for a large, geographically dispersed operation; the costs of retaining the risk, including maintaining adequate contingency reserves for likely losses; and the cost of administering a selfinsurance program, including the cost of purchasing excess-of-loss coverage from a reinsurance market. 


\section{Insurance Definitions}

As noted, insurance coverage - including that for PV systems - is categorized as either property or casualty insurance, but these are often packaged together, especially for homeowners and small commercial insureds. Casualty (also referred to as liability) insurance can also include surety or other specialty coverage. Causes of loss are referred to as perils - for example, fire, wind, hail, theft.

Insurance contracts specify policy limits that indicate the maximum total dollar amount available to be paid for a claim arising from a covered peril. Limits are expressed as a per occurrence limit, which indicates the maximum payout from any single loss event; and an aggregate limit, which caps the maximum payout for all covered losses within the policy period. Policy periods - the time between commencement and the end of the coverage - are typically 1 year, with annual renewals with a review of loss exposures and recalculation of premiums. Most coverage is provided on an occurrence basis, which means that the policy covers losses arising from events that occur during the policy period. Losses caused by an event that occurs before or after a policy period are not covered under that contract, presumably because losses that occur before or after the specific policy period would be covered under a separate policy. Some liability coveragesuch as product liability or professional liability (also called errors-and-omissions) insuranceprovide coverage on a claims made basis. This means that the policy covers claims that are made within the policy period regardless of when the event that caused the loss occurred.

Insurance policies specify deductibles - an amount of loss that the insured retains. If a loss exceeds the deductible amount, the insurer pays the amount of loss exceeding that deductible up to the policy limits. Because most losses are small, deductibles help insureds and insurance companies reduce the cost of coverage. For insurance companies, this reduces both the costs of claims paid out as well as the administrative cost of processing very small claims where the cost of administration might far exceed the actual dollar amount of the loss. Selecting higher deductibles is common to reduce insurance premiums. Commercial policyholders typically choose higher deductibles based on past experience, called the normal loss expected. This enables insureds to manage smaller losses as part of normal operations and maintain lower insurance costs.

Three factors are considered when setting policy limits: the probable maximum loss, the maximum foreseeable loss, and the total insurable value. Insurance underwriters base their premium calculations on their estimate of the probable maximum loss - the largest amount of loss the insured is likely to sustain based on their loss exposures. Limits of coverage are guided by both the maximum foreseeable loss, which represents the worst-case loss scenario; and the total insurable value, which, for property coverage, includes the total reported value of physical assets as well as annual business income.

Sometimes an insurance buyer, in an attempt to save on insurance premiums, reduces limits of coverage because it is unlikely that the insured would suffer a total loss (maximum foreseeable loss) or even a major loss (probable maximum loss) within any given policy period. Property policies include coinsurance clauses to encourage insureds to purchase adequate insurance limits at least equal to the maximum foreseeable loss. Coinsurance clauses stipulate that the total limit of property coverage must equal some percentage - e.g., commonly $80 \%$ (Bache 2011) —of the 
property value. If the total limit of the coverage is less than that percentage, the insurance company might pay only the proportion of the loss that the coverage limit is to the coinsurance limit. For example, to save money, an insured might decide to purchase only a $\$ 500,000$ limit on a property with a $\$ 1,000,000$ replacement value, reasoning that the probable maximum loss is $\$ 500,000$. But if the insurance-to-value coinsurance limit is $80 \%(\$ 800,000)$, any covered losses would be paid at $62.5 \%$ (calculated as $\$ 500,000 / \$ 800,000$ ). This provides an incentive for the insured to purchase a coverage limit of at least $\$ 800,000$. In the case of a total loss, however, the most the insurance company will pay is the policy limit, leaving the insured to bear the portion of the loss that exceeds this limit. Often minimum limits of coverage are required by legal statute or contract between various parties - for example, by the financier of a PV system or the mortgage holder on a property (land or building).

Another way of controlling insurance costs for PV plants is through selecting the types of perils that are covered or excluded. Policies are generally written as all risk, which means that there is coverage for all risks unless specifically excluded. Policies can also be written on a named peril basis, which covers only losses caused by those perils that are listed. Insurance policies contain exclusions for specified types of losses, perils, or conditions. Insurance policies exclude certain types of perils, such as earthquakes or ground movements, because the potential losses are too large or incalculable. Standard insurance policy language is amended by endorsement, which are modifications to contract terms that can either expand or limit coverage.

PV system operators with very large systems or fleets of systems (insurance buyers with very large insurable values) might need to obtain coverage from multiple insurance companies because these values could exceed a given insurance company's capacity (the amount the insurance company is willing or able to absorb for any one loss). Very large capacity can be provided in one of two ways: by using excess-of-loss or quota share coverage.

Under excess-of-loss coverage, one insurance company provides the primary layer of coverage, and one or more other insurers provide additional limits that are invoked if the primary layer is exceeded. The deductibles for excess-of-loss policies match the limit of either the primary policy or the next layer of coverage. Premiums for excess coverage layers reflect the lower probability of having losses that exceed the lower layer limits.

Quota share arrangements involve multiple insurers sharing premiums and loss limits with each receiving a percentage of premiums in accordance with their percentage share of losses. For example, on a $\$ 1$ billion project, an insurer taking a $2 \%$ quota share would be responsible for paying 2\% of losses up to their $\$ 20$ million loss limit. By sharing risks in this way, insurers can provide the very large aggregate limits these projects or entities require.

Traditionally, insurance companies purchase reinsurance contracts to cap their total losses from a type of exposure (such as property coverages). Some reinsurers also provide property insurance coverage directly to insurance buyers with very large insurable values. These arrangements often require the insured to retain losses below a fairly high threshold.

Although not technically insurance, equipment warranties are a type of performance guarantee of product quality and performance provided by manufacturers that are similar to insurance. A product warranty covers defects in materials and workmanship, and a performance warranty 
guarantees a certain power output over a specified time. PV modules might have warranties for 20 or 25 years, inverters for perhaps 10 years, and the engineering procurement and construction company might warrant a whole system for up to 5 years. Performance warranties guarantee a declining amount of output in anticipation of some expected degradation in system performance. A warranty may be voided by mishandling items, by failing to provide specified preventative maintenance, or by not observing instructions or conditions of the warranty. There can be expenses incurred in enforcing a warranty, such as testing each module; and labor to replace, ship and reinstall. Financiers and asset managers consider the size, reputation, credit rating, and diversification of companies offering both warranties and insurance. Warranty insurance can also be purchased that extends manufacturer warranties. The cost of such insurance can be reduced by consolidating portfolios rather than by insuring projects individually, by registering and retaining warranties, and by carefully observing all warranty conditions and all procedures involved in warranty service. The combination of quality and warranty coverage determines the outcome in terms of the resulting performance of each warranted item and thus for the whole PV system. Even excellent warranty service, however, can only partially compensate for failure-prone components (NREL et al. 2018). 


\section{Types of Losses Involving Photovoltaic Equipment}

In discussing specific insurance coverage considerations for PV system owners, operators, and third parties, it is helpful to understand typical causes of loss to PV systems. For insight into the range of insured losses involving PV equipment, claims costs, and most significant perils, we analyzed data from Verisk, the leading services organization compiling data on property-casualty insurance claims. This analysis considers the causes of the most frequent and severe losses as well as geographic claims differences that can drive differences in insurance premiums or exclusions for certain types of coverage in different locations.

Although Verisk is the single largest aggregator of claims data in the United States, not all insurers report claims data to industry aggregators. The Verisk data we analyzed do not represent all U.S. insurance claims nor do they represent all Verisk claims for subject years. The Verisk data we analyzed included only claims that included identifiable solar equipment (solar electric panels and arrays, battery backup, or converters). These data did not include any claim that did not indicate solar equipment. Verisk data included two values: (1) the value of solar equipment included in each claim and (2) the total payment for the entire claim.

As of May 2020, Verisk identified 15,128 property-casualty insurance claims from 2014-2019 that included PV equipment. The total value for the solar items included in these claims was $\$ 60.8$ million. This compares to the total payment for these claims, including nonsolar items, of more than $\$ 1.2$ billion. These data on claim values included only amounts exceeding policy deductibles. As shown in Figure 1, most (98\%) claims were residential, but the average value of the solar items for commercial claims was nearly three times the corresponding amount for residential claims $(\$ 10,576$ versus $\$ 3,901)$, whereas the average total claim size for commercial policies (utility, commercial, and third parties) was nearly twice that for residential $(\$ 154,402$ versus $\$ 79,076)$. 


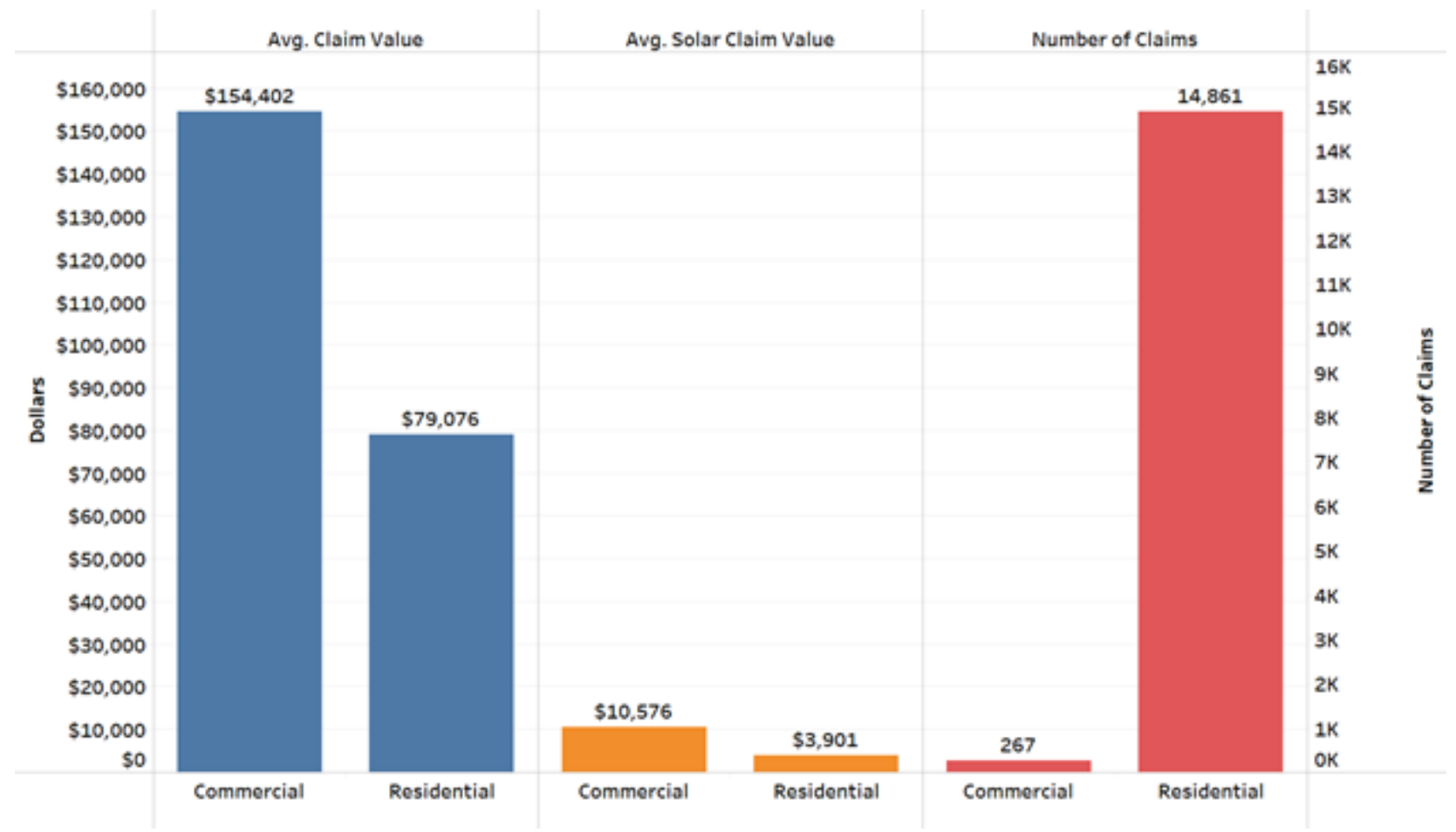

Figure 1. Average claim and average solar claim value across residential

Major causes of loss during these 6 years included fire, lightning, theft and vandalism, and freeze (including ice and snow). Other assorted causes of loss included other weather, animal, automobile/vehicle collision, collapse, earthquake, falling trees, food spoilage, and structural defect.

As shown in Figure 2, overall, the three most frequent causes of loss of claims including solar equipment for both residential and commercial were hail (53\% of the number of claims for all losses including solar items), wind (32\%), and fire ( $8 \%)$. 


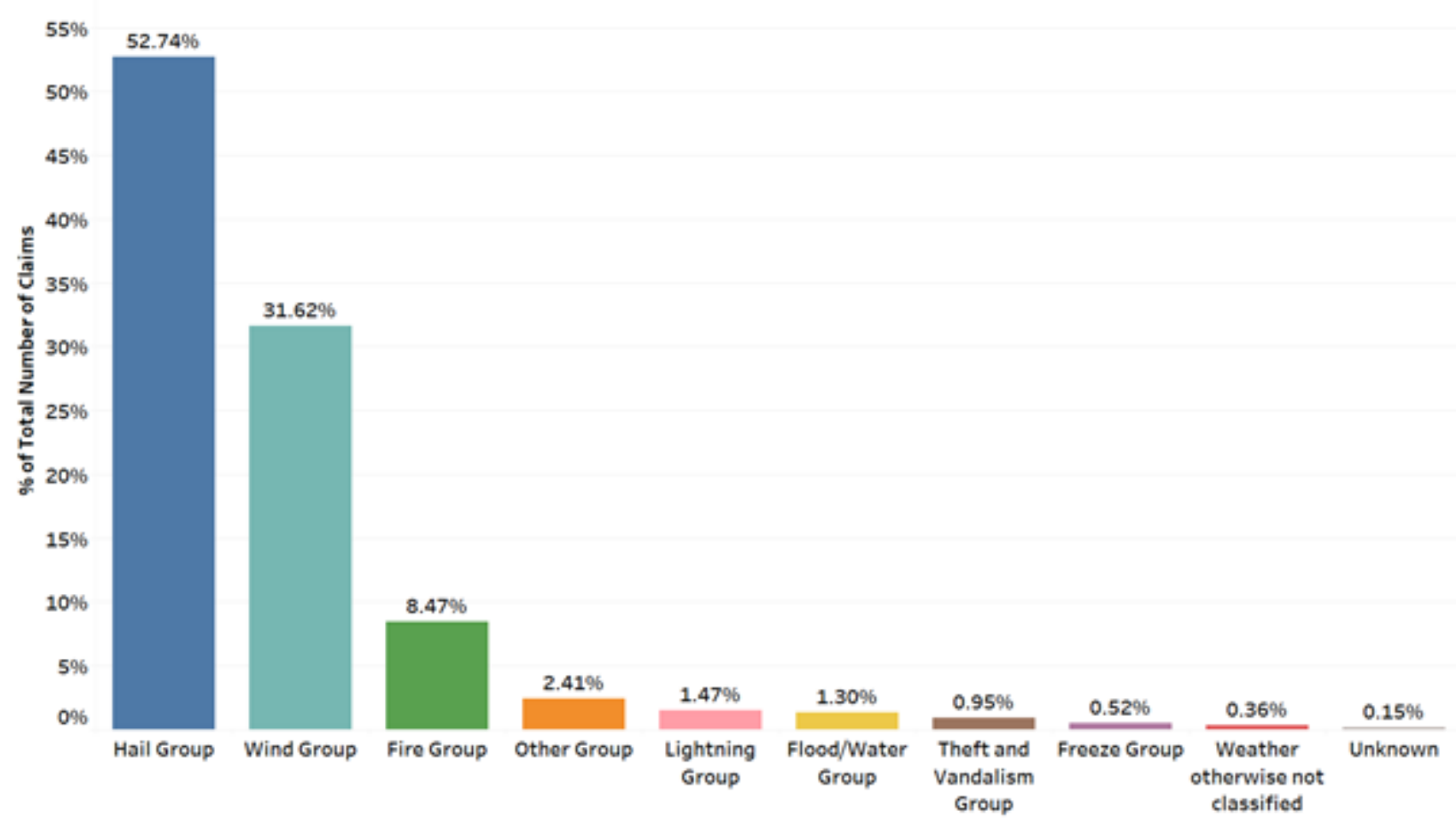

Figure 2. Percentage of claims by cause of loss

Figure 3 illustrates that fire had the largest average solar item claim cost $(\$ 17,308$ per claim); followed by lightning $(\$ 9,746)$; theft and vandalism $(\$ 5,770)$; freeze, including ice and snow $(\$ 5,288)$; and all other weather $(\$ 3,702)$, all with larger average solar item values per claim than either hail or wind, which caused the most frequent losses. 


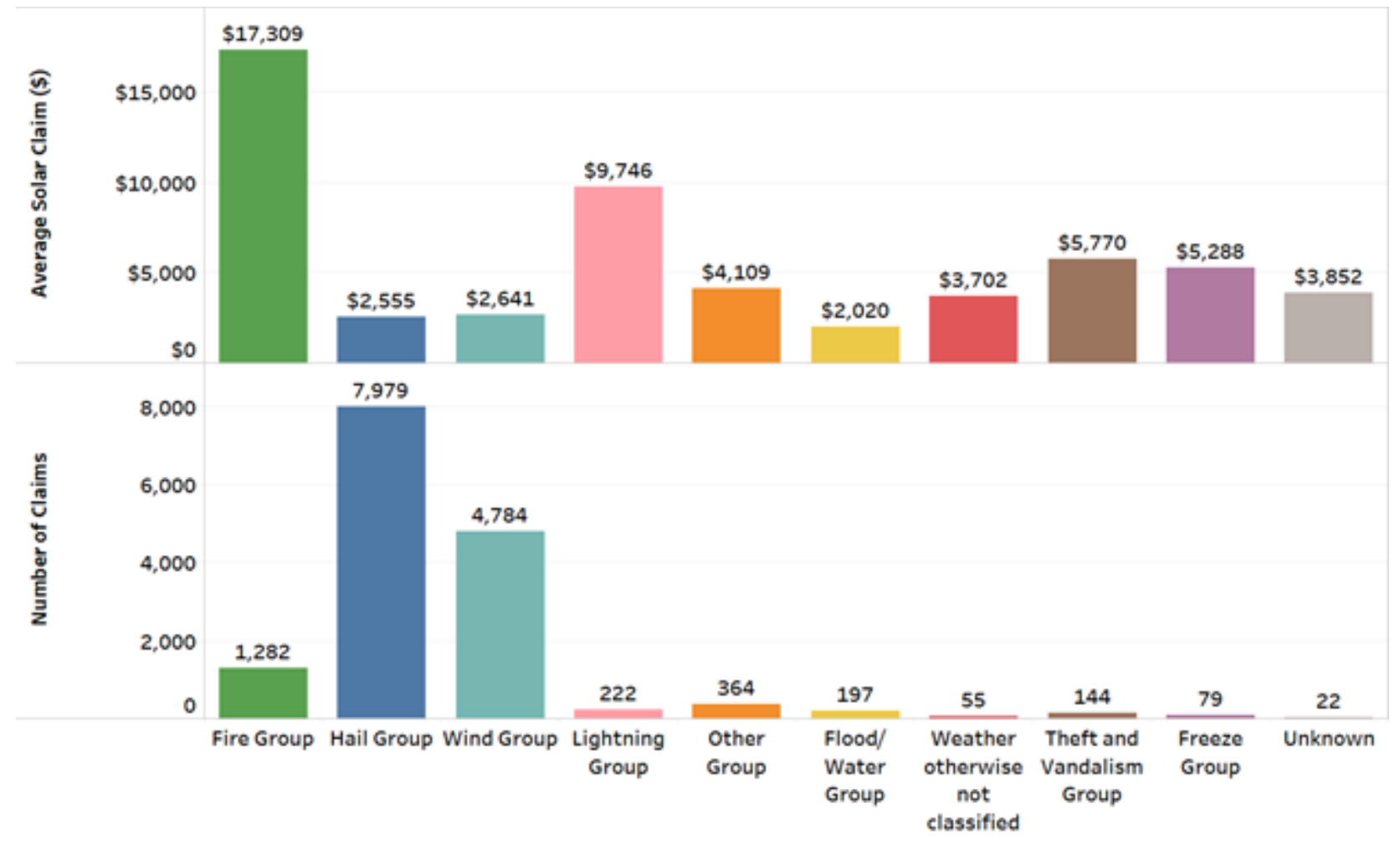

Figure 3. Claims involving solar items by cause of loss

Table 1 shows that the largest average loss to solar items for residential claims was caused by fire, followed by lightning, then theft and vandalism. For commercial claims, the largest average loss to solar items was caused by freeze, ice, and snow, followed by fire, then wind.

Table 1. Average Claim Value (\$) of Solar Items by Cause of Loss

\begin{tabular}{llllllll}
\hline $\begin{array}{l}\text { Policy } \\
\text { Type }\end{array}$ & $\begin{array}{l}\text { Fire } \\
\text { Group }\end{array}$ & $\begin{array}{l}\text { Lightning } \\
\text { Group }\end{array}$ & $\begin{array}{l}\text { Theft and } \\
\text { Vandalism } \\
\text { Group }\end{array}$ & $\begin{array}{l}\text { Freeze } \\
\text { Group }\end{array}$ & $\begin{array}{l}\text { Wind } \\
\text { Group }\end{array}$ & $\begin{array}{l}\text { Hail } \\
\text { Group }\end{array}$ & $\begin{array}{l}\text { Flood/Water } \\
\text { Group }\end{array}$ \\
\hline Residential & 17,141 & 9,991 & 6,263 & 4,195 & 2,531 & 2,499 & 2,004 \\
Commercial & 22,954 & 2,248 & 2,881 & 32,964 & 9,956 & 7,785 & 2,341 \\
\hline
\end{tabular}

These data expose how solar equipment is affected by different perils. Hail and wind represented a large number of claims, but the losses per claim were typically modest (likely/typically some module breakage); whereas fire had a fewer number of claims but higher losses (often the complete loss of the system). PV arrays - which are often located on a rooftop or are similarly exposed - suffered more damage from hail and wind than other insured property, such as walls and windows. 
Some geographic locations had a large concentration of claims around specific perils, and the largest number of claims around each peril tended to cluster around specific states. ${ }^{2}$ Nearly every state, however, had at least some claims including solar items from common perils. For example, hail caused the largest number of claims with solar items $(7,979)$. As illustrated in Figure 4, two states - Colorado (3,113 claims with total value of solar items of \$7.9 million) and Texas (1,968 hail claims with total value of solar items of $\$ 6.3$ million) — had the largest number of claims and the largest amount of claims costs for solar items. Only three states-New Hampshire, Rhode Island, and Alaska - as well as Puerto Rico, reported no hail claims with solar items during this 6year period. ${ }^{3}$

Hail: (\$) Solar Items Total by State from 2014-2019 for Residential and Commercial

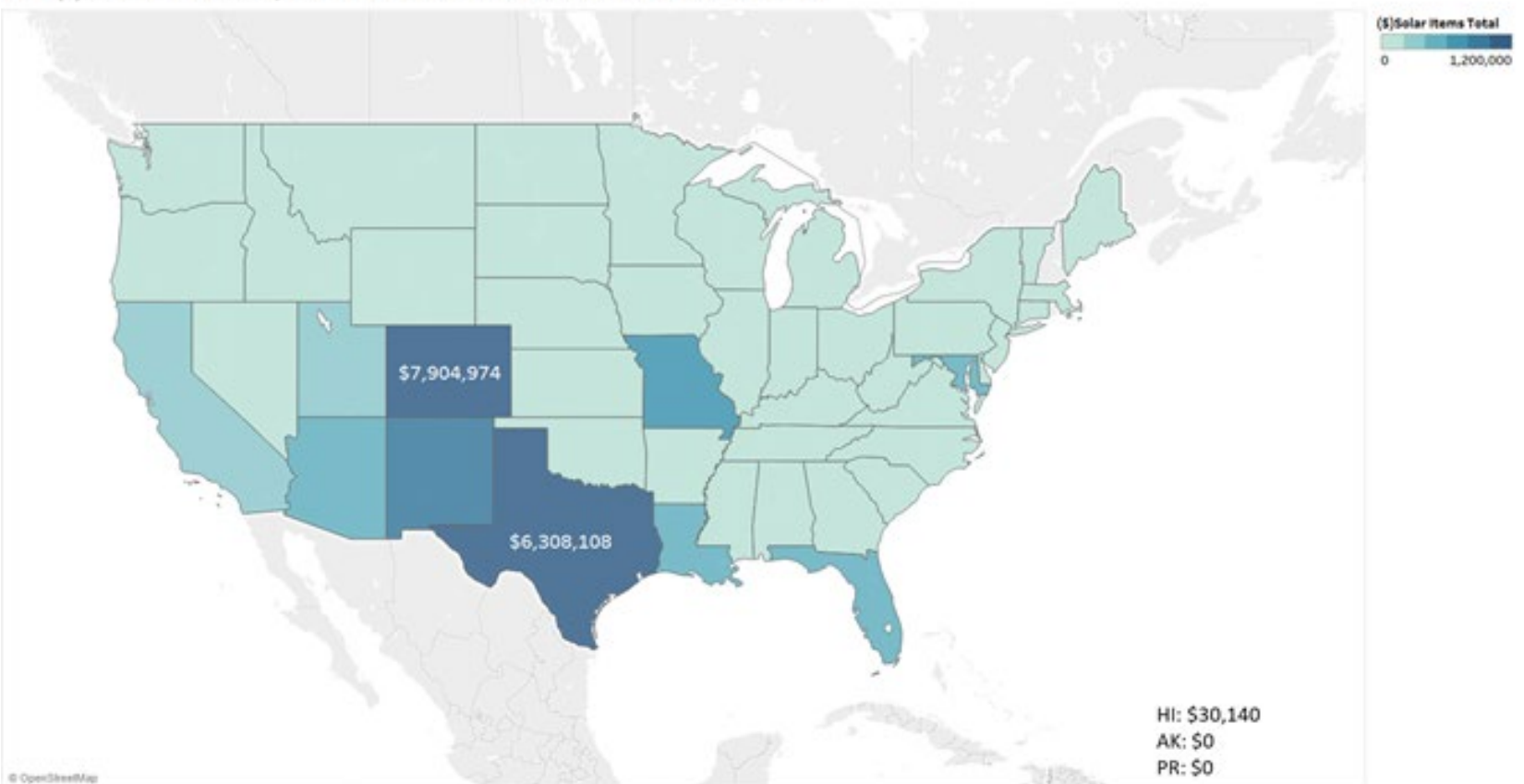

Figure 4. Colorado and Texas had the largest concentration of hail-related solar equipment losses.

Wind caused the second largest number of claims with solar items $(4,784)$ and the third largest amount for solar items ( $\$ 12.6$ million) and total claim value (\$125 million). Hurricanes or named storms (both grouped in the wind category) were specified as the cause of loss in 603 claims, with costs of \$1.1 million for solar items and \$20 million in total claim value. ${ }^{4}$ Tornadoes were indicated in 92 claims for $\$ 377,010$ in costs for solar items and $\$ 4.2$ million in total claim value.

Figure 5 shows the state distribution of wind-related losses. This shows a concentration of claims in Florida (1,067 claims, \$1.7 million cost of solar items, and \$32 million in total claim value);

\footnotetext{
${ }^{2}$ Because Verisk data do not include claims data from all insurance companies, certain states might be over- or underrepresented compared to all similar insurance claims during the 6-year period.

${ }^{3}$ This does not mean that New Hampshire, Rhode Island, and Alaska had no losses from hail—only that there were no claims from these states with solar items caused by hail.

${ }^{4}$ This does not mean that these are the only hurricane-related claims - only that these are the claims identified in these data.
} 
and Hawaii, Arizona, Maryland, Texas, and California had more than 300 wind-related claims with solar items. Wind-related claims with solar items were reported in all states except South Dakota and Alaska.

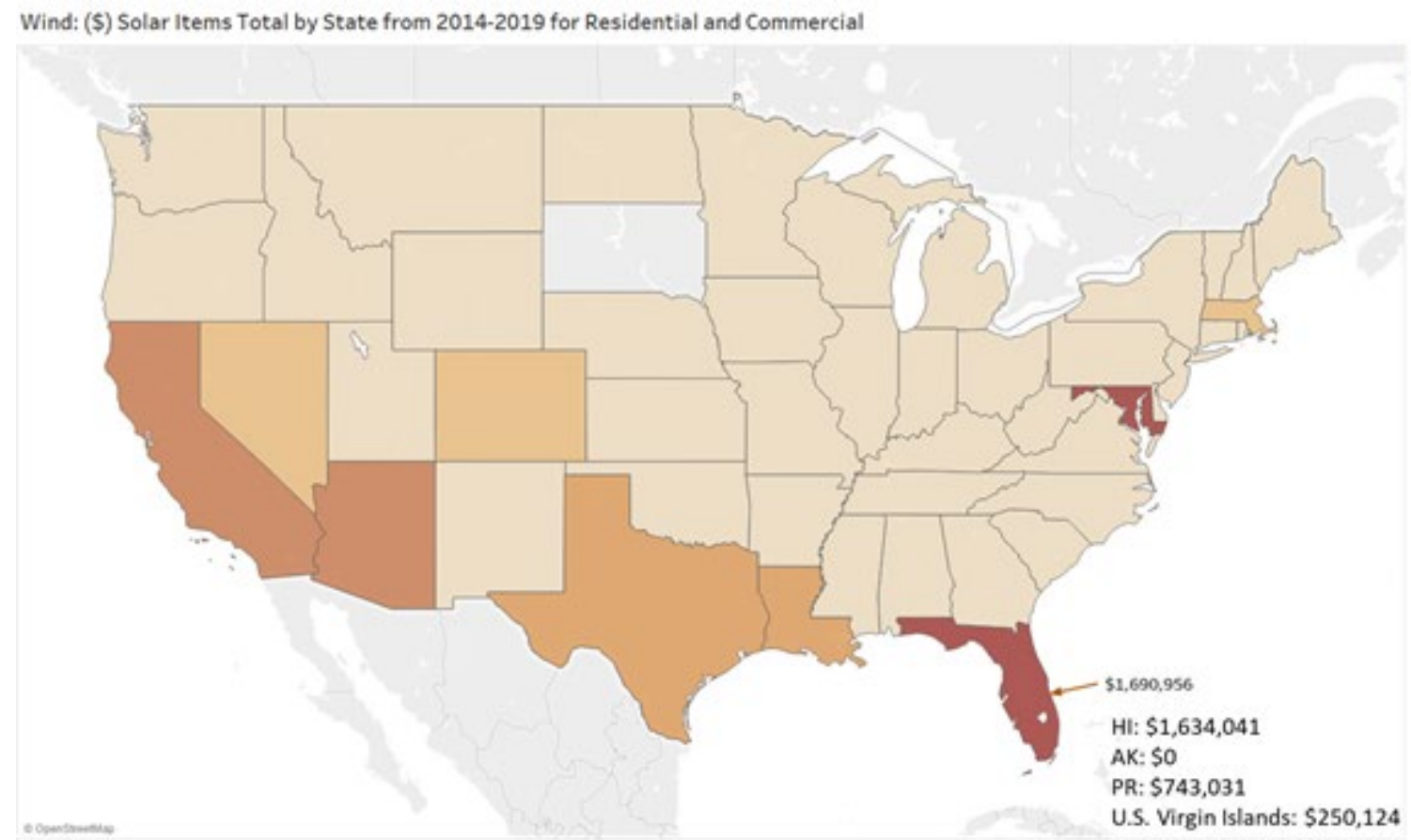

Figure 5. Wind-related losses were concentrated in Florida.

Figure 6 shows how both residential and commercial fire claims, which accounted for the largest claim amounts for solar equipment, were driven by California wildfires. Fire losses in California were clustered around certain months: October 2017 (384 claims, \$10 million in solar items, and $\$ 422$ million in total claim value), November 2018 (179 claims, \$4 million in solar items, and $\$ 138$ million in total claim value), and July 2018 (76 claims, $\$ 1.5$ million in solar items, and \$46 million in total claim value).

Colorado, with 43 claims, was the only other state with more than 30 fire claims involving solar items. Only three states - South Dakota, Alabama, and West Virginia - did not report any claims with solar items related to fire during the 6-year period. 


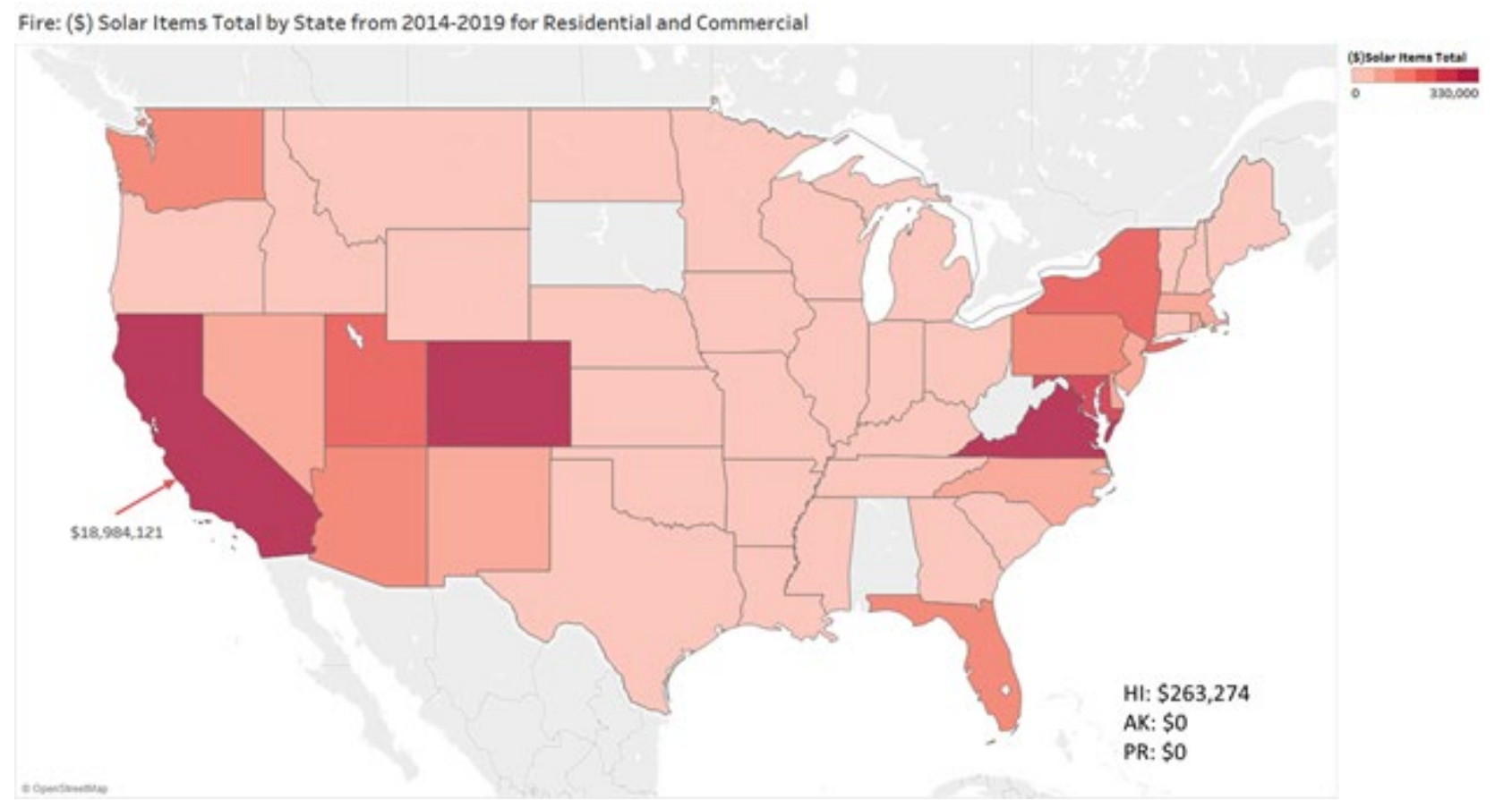

Figure 6. California had the largest concentration of fire-related solar equipment losses.

Lightning caused loss for the fourth largest solar item value, with 222 claims indicating this as the cause of loss for $\$ 2.2$ million solar items and \$56 million in total claim value. Other causes of loss with more than 100 claims during the 6-year period were flood/water, freeze (including ice and snow), and theft and vandalism.

Finally, looking at the distribution of loss size is helpful to understand potential loss exposure. Table 2 shows the distribution of the Verisk data by peril and illustrates that although most losses are smaller, the higher average solar equipment loss size is influenced by a relatively few, very large claims. This points out the importance of adequate coverage limits for large loss events. 
Table 2. Statistics on Solar Item Losses by Type

\begin{tabular}{|c|c|c|c|c|c|c|c|c|c|c|}
\hline $\begin{array}{l}\text { Solar Claims } \\
\text { Total }\end{array}$ & $\begin{array}{l}\text { Fire } \\
\text { Group }\end{array}$ & $\begin{array}{l}\text { Wind } \\
\text { Group }\end{array}$ & $\begin{array}{l}\text { Hail } \\
\text { Group }\end{array}$ & $\begin{array}{l}\text { Freeze } \\
\text { Group }\end{array}$ & $\begin{array}{l}\text { Lightning } \\
\text { Group }\end{array}$ & $\begin{array}{l}\text { Theft and } \\
\text { Vandalism } \\
\text { Group }\end{array}$ & $\begin{array}{l}\text { Flood/ } \\
\text { Water } \\
\text { Group }\end{array}$ & $\begin{array}{l}\text { Weather } \\
\text { Otherwise } \\
\text { Not } \\
\text { Classified }\end{array}$ & $\begin{array}{l}\text { Other } \\
\text { Group }\end{array}$ & Unknown \\
\hline Number of claims & 1,282 & 4,784 & 7,979 & 79 & 222 & 144 & 197 & 55 & 364 & 22 \\
\hline $\begin{array}{l}\text { Average solar } \\
\text { claim value }\end{array}$ & $\$ 17,309$ & $\$ 2,641$ & $\$ 2,555$ & $\$ 5,288$ & $\$ 9,746$ & $\$ 5,770$ & $\$ 2,020$ & $\$ 3,702$ & $\$ 4,109$ & $\$ 3,852$ \\
\hline Maximum & $\$ 281,428$ & $\$ 250,617$ & $\$ 180,529$ & $\$ 94,921$ & $\$ 82,481$ & $\$ 52,439$ & $\$ 26,103$ & $\$ 40,136$ & $\$ 86,157$ & $\$ 28,163$ \\
\hline Median & $\$ 10,140$ & $\$ 1,098$ & $\$ 1,203$ & $\$ 2,358$ & $\$ 3,410$ & $\$ 2,383$ & $\$ 1,210$ & $\$ 1,340$ & $\$ 1,365$ & $\$ 1,249$ \\
\hline Standard deviation & $\$ 22,631$ & $\$ 6,604$ & $\$ 5,027$ & $\$ 12,143$ & $\$ 14,561$ & $\$ 7,919$ & $\$ 2,839$ & $\$ 7,237$ & $\$ 8,440$ & $\$ 6,713$ \\
\hline
\end{tabular}




\section{Purchasing Insurance Coverage for Photovoltaic Systems}

Good insurance coverage is key to mitigating financial risk, but coverage needs differ significantly based on whether the type of insurance exposure is personal or commercial. For example, as noted in the discussion of claims, commercial claims could include those from a broad range of PV systems, including utility-scale PV energy providers, businesses with rooftop $\mathrm{PV}$, project consultants, system installers, or other third parties. In this section, we discuss types of coverage and insurance needs arising from PV systems for different types of buyers. This section focuses on items of particular interest or special coverage needs from PV system development, installation, or ownership. Appendix A provides a more complete list of insurance coverage that these different types of entities might require.

\subsection{Residential Homeowners}

For residential homeowners, PV systems are covered under homeowners' policies that cover both property and liability exposures. Property coverage includes the dwelling with attached fixtures, such as rooftop PV systems and detached structures. PV systems installed on the roof of a home are covered under the dwelling coverage and limits; whereas systems installed on a detached structure, such as a garage, or ground-mounted systems might be subject to a separate, often lower limit of coverage.

Homeowners' policies also include liability coverage protecting the homeowner against financial loss from harm to others, such as liability for death or injury to persons or damage to property owned by others that occurs on the homeowner's premises. An umbrella policy provides increased limits for both the homeowners' coverage and personal automobile liability coverage.

A homeowners' policy covers liability losses only for which the homeowner is legally liable, meaning that the homeowner is at fault for causing the bodily injury or property damage. The homeowners' policy will not cover any damage to the owned property caused by installers or other third-party contractors, nor will it provide coverage for faulty installation or subsequent breakdown. For this reason, homeowners should obtain proof that the contractor maintains adequate insurance coverage and limits prior to starting work because the risks are greatest during installation. At minimum, installers, contractors, and project designers should provide proof of general liability and professional liability insurance (also known as errors-andomissions insurance). Professional liability insurance covers claims arising from PV system design, consulting, engineering, or installation.

\subsection{Small Commercial}

Similarly, coverage for PV systems for small commercial insureds are typically included in a small business owner's package that includes commercial property, commercial general liability, and commercial auto (property and liability) coverage. As with residential coverage, commercial umbrella policies can be obtained to increase overall limits of liability. If the business operates from a leased property, there could be special insurance considerations for owned PV systems attached to a third-party's property as well as for damage to the leased property. In addition to ensuring coverage for loss from more frequently occurring perils, commercial PV system owners 
should ensure that they have coverage for theft of PV system components, which is a particular concern during installation or maintenance, and for systems installed on nonowned property.

Like homeowners, small commercial insureds should require PV system designers, engineers, installers, or service providers to provide proof of adequate general liability and professional liability/errors-and-omissions insurance coverage. Lease contracts often specify types and limits of insurance coverage that need to be maintained by both the lessor and the lessee. Rather than rely on contracts that set minimum levels of insurance, however, even small commercial insureds should work with an agent or broker knowledgeable about the insured's business and exposures, including their PV system, to ensure appropriate coverages at a fair price and to tap into any available expertise for better managing overall risk.

\subsection{Large Commercial}

Large commercial entities often have complex exposures that are well suited to using a risk management team. The team could include an in-house risk manager or risk management staff and specialized insurance brokers or agents who understand all aspects of the business and who have access to specialized underwriters. A risk management team ensures that the business has all risks inventoried and has appropriate risk mitigation strategies in place, including appropriate insurance coverage customized to the situation. Specialized risk managers can evaluate existing facilities, fleets, portfolios of properties, or the design for yet-to-be-built systems, including any operation-and-maintenance program to quantify loss potential. This allows the risk management team to design a complete program to cost-effectively address risks. The risk management team needs to be kept informed of any plans for new construction or site/operational expansion to ensure adequate coverage for the development phase of any project and to review contracts to ensure that contractors - such as developers, architects, construction companies, and installersmaintain adequate insurance coverage and limits. The team's role could also include designing self-insured programs and accessing excess coverage from reinsurance markets. The team could also be responsible for ensuring that all contracts address risk mitigation and specify required insurance coverage. Risk management can provide a better understanding of risks that could impact the performance of the business or PV plant beyond those for which insurance is available.

Property insurance covers direct physical loss, damage, or destruction to policyholders' property from a wide range of perils. Other causes of property loss include theft of PV system components - which is of special concern during construction-water and flooding, damage from animals, vehicle collision, collapse, earthquake, falling trees, and structural defect. For some commercial insureds, the loss of goods or property due to spoilage can also be a significant exposure - for example, from loss of refrigeration due to a power outage. An inland marine policy can cover property in transit, such as PV system components shipped to the project site from manufacturer locations or that are shipped off-site for repair.

Business interruption insurance-which covers the loss of business income or of incurring an extra expense in case of a covered property loss - is also important for large commercial insureds because losses from not being able to operate the business can often be much larger than losses from the actual direct physical damage causing the shutdown. Business interruption losses from noncovered perils, however, are not included under standard business interruption coverage. Property insurance policies typically exclude losses from mechanical or equipment breakdown 
(HSB Canada 2020). If an operation that relies on a PV-plus-battery system to supply its power, particularly to meet sustainability goals, does not have coverage for lost business income, a mechanical or equipment breakdown could put the system — and the business - out of operation for weeks. Separate policies are available for PV system mechanical or equipment breakdown that can bridge this coverage gap.

Commercial general liability insurance protects from liability for death or injury to persons (nonowners or employees) or damage to property owned by third parties occurring on the insured's premises or arising from their products or business operations, including from an owned PV system. Builders' risk policies, used during construction, are designed to cover the additional exposures involved in new construction or expansion. As mentioned, all contractswhether for constructing or expanding systems or for ongoing operation and maintenanceshould specify the types of coverage and limits that the contractors need to maintain.

Table 3 provides examples of insurance requirements with coverage and minimum limits from a sample of publicly available requests for proposals for the development of new or expanded commercial PV systems. All have minimum requirements for commercial general liability limits from $\$ 1$ million-\$5 million, with some specifying separate products/completed operation limits. Most require commercial auto liability limits from $\$ 500,000-\$ 1$ million, with some requiring umbrella or excess liability insurance increased limits to $\$ 12$ million. Most also require workers' compensation coverage with limits ranging from whatever is required by state statue up to $\$ 1$ million. Other limits and coverage specified include $\$ 1$ million of professional liability/errorsand-omissions insurance, up to $\$ 1$ million in employers' liability coverage (which extends coverage for claims not related to workers' compensation by employees), and $\$ 1$ million for environmental/pollution liability coverage. One request for proposal also specifies minimum limits for coverages typically included in commercial general liability policies, of $\$ 1$ million for personal and advertising liability, $\$ 50,000$ for fire damage, and \$5,000 medical expense. 
Table 3. Insurance Requirements from Requests for Proposals for Commercial-Scale PV Systems

\begin{tabular}{|c|c|c|}
\hline $\begin{array}{l}\text { System } \\
\text { Categories } \\
\text { and Types }\end{array}$ & \multicolumn{2}{|l|}{ Developer's Insurance Requirements } \\
\hline $500-k W$ & \multicolumn{2}{|c|}{ 1. Commercial general liability: at least $\$ 5,000,000$} \\
\hline carport & \multicolumn{2}{|c|}{ 2. Business automobile liability: at least $\$ 1,000,000$} \\
\hline $\begin{array}{l}10-\mathrm{MW} \\
\text { ground } \\
\text { mounted on } \\
\text { closed } \\
\text { landfilla }\end{array}$ & \multicolumn{2}{|c|}{ 3. Workers' compensation: at least $\$ 1,000,000$} \\
\hline \multirow{3}{*}{$\begin{array}{l}\text { Roof- } \\
\text { mounted; } \\
\text { commercial }^{b}\end{array}$} & Developer's insurance obligations: & Host's insurance obligation: \\
\hline & $\begin{array}{l}\text { 1. Comprehensive commercial general } \\
\text { liability: at least } \$ 2,000,000\end{array}$ & 1. Commercial general liability: $\$ 3,000,000$ \\
\hline & 2. Excess liability: at least $\$ 10,000,000$ & \\
\hline \multirow{4}{*}{$\begin{array}{l}\text { Roof } \\
\text { mounted; } \\
\text { commercial } \\
\text { (50-kW dc } \\
\text { system size)c }\end{array}$} & \multirow{4}{*}{\multicolumn{2}{|c|}{$\begin{array}{l}\text { 1. Workers' compensation: } \$ 1,000,000 \\
\text { 2. Commercial comprehensive liability: } \$ 1,000,000 \\
\text { 3. Business auto liability: } \$ 500,000 \text { per person; } \$ 1,000,000 \text { per accident } \\
\text { 4. Umbrella excess liability: } \$ 1,000,000\end{array}$}} \\
\hline & & \\
\hline & & \\
\hline & & \\
\hline \multirow{11}{*}{$\begin{array}{l}\text { Ground- } \\
\text { mounted } \\
(100 \mathrm{~kW}-1 \\
\mathrm{MW}) ; \text { if } \\
\text { legislation } \\
\text { passes, up to } \\
5 \mathrm{MW}^{\mathrm{d}}\end{array}$} & \multicolumn{2}{|l|}{ 1. Commercial general liability: $\$ 2,000,000$} \\
\hline & \multicolumn{2}{|c|}{ 2. Products-completed operations in aggregate: $\$ 2,000,000$} \\
\hline & \multicolumn{2}{|l|}{ 3. Personal and advertising: $\$ 1,000,000$} \\
\hline & \multicolumn{2}{|l|}{ 4. Each occurrence injury: $\$ 1,000,000$} \\
\hline & \multicolumn{2}{|l|}{ 5. Fire damage (any one fire): $\$ 50,000$} \\
\hline & \multicolumn{2}{|c|}{ 6. Medical expense (any one person): $\$ 5,000$} \\
\hline & \multicolumn{2}{|c|}{ 7. Commercial automobile liability: $\$ 1,000,000$} \\
\hline & \multicolumn{2}{|c|}{$\begin{array}{l}\text { 8. Workers' compensation: } \$ 100,000 \text { (each accident) } / \$ 500,000 \text { (disease—policy limit)/ } \\
\$ 100,000 \text { (disease—each employee) }\end{array}$} \\
\hline & \multicolumn{2}{|l|}{ 9. Commercial umbrella: $\$ 5,000,000$} \\
\hline & \multicolumn{2}{|c|}{ 10. Others; professional/errors and omissions: $\$ 5,000,000$} \\
\hline & \multicolumn{2}{|c|}{ 11. Environmental—pollution liability: $\$ 1,000,000$} \\
\hline \multirow{4}{*}{$\begin{array}{l}\text { Ground } \\
\text { mounted, } \\
\text { roof } \\
\text { mounted; } \\
\text { carport; } \\
\text { total } 2.73 \\
\text { MWe }\end{array}$} & \multirow{4}{*}{\multicolumn{2}{|c|}{$\begin{array}{l}\text { 1. Workers' compensation: not less than } \$ 500,000 \\
\text { 2. Automobile liability: at least } \$ 500,000 \\
\text { 3. Commercial general liability: } \$ 1,000,000 \text { and } \$ 2,000,000 \text { in aggregate } \\
\text { 4. Professional liability: not less than } \$ 1,000,000 \text { and } \$ 2,000,000 \text { in aggregate }\end{array}$}} \\
\hline & & \\
\hline & & \\
\hline & & \\
\hline \multirow{6}{*}{$\begin{array}{l}\text { Roof } \\
\text { mounted/ } \\
\text { ground } \\
\text { mounted }\end{array}$} & \multicolumn{2}{|c|}{ 1. Workers' compensation-Virginia statutory benefits } \\
\hline & \multicolumn{2}{|c|}{ 2. Employers' liability: $\$ 1,000,000$ each accident and each employee } \\
\hline & \multicolumn{2}{|c|}{ 3. Commercial general liability: $\$ 1,000,000$} \\
\hline & \multicolumn{2}{|c|}{ 4. Business automobile liability: $\$ 1,000,000$ combined single limit each occurrence } \\
\hline & \multicolumn{2}{|c|}{ 5. Umbrella or excess liability: $\$ 1,000,000$ each occurrence } \\
\hline & \multicolumn{2}{|c|}{ 6. Professional (errors-and-omissions) liability: $\$ 1,000,000$ per claim } \\
\hline
\end{tabular}




\begin{tabular}{ll}
\hline $\begin{array}{l}\text { System } \\
\text { Categories } \\
\text { and Types }\end{array}$ & Developer's Insurance Requirements \\
\hline $\begin{array}{l}\text { Roof } \\
\text { mounted/ }\end{array}$ & $\begin{array}{l}\text { 1. Commercial general liability: not less than } \$ 1,000,000 \text { each occurrence/ } \\
\text { ground }\end{array}$ \\
$\begin{array}{l}\text { mountedg } \\
\text { 2. Business automobile liability: minimum of } \$ 1,000,000 \text { each occurrence }\end{array}$ \\
$\begin{array}{l}\text { 3. Employers' liability coverage: minimum limits of } \$ 500,000 \text { each accident and } \\
\$ 500,000 \text { each employee disease }\end{array}$ \\
\hline
\end{tabular}

a Anne Arundel County 2015

b Cape \& Vineyard Electric Cooperative, Inc. 2017

c Kaskaskia College 2020

d City of Concord, New Hampshire 2019

e Solar Workgroup of Southwest Virginia 2019

${ }^{f}$ Loudoun County Public Schools 2019

g Buncombe County, North Carolina 2019

\subsection{Utility-Scale Photovoltaics}

In addition to the considerations of large commercial insurance buyers, power generation system owners and operators might have special insurance needs that depend on the characteristics of the system; the ownership, operation, and management structure; and the ownership of the land on which the system is sited. As with other large commercial operations, a specialized risk management team should inventory risks and ensure appropriate risk mitigation strategies. These strategies could include developing self-insurance programs, accessing specialty coverage, obtaining excess-of-loss coverage from the reinsurance market, and ensuring that all contracts address risk mitigation. Risk management can provide an important perspective on risks throughout the life of the system that could impact the performance of the business or PV plant beyond those for which insurance is available.

Initial construction or expansion gives rise to additional exposures addressed with builders' risk (also called delay in startup) insurance that covers damage or injury during the construction stage of a project. Large projects might require a surety performance bond that guarantees adequate funds to finish the project if the contractor is unable to complete it. As noted for large commercial insureds, the risk management team should review all contracts to specify coverage and limit requirements for firms involved in all aspects of the development, design, construction, operation, and/or management of the system. Table 4 shows example insurance requirements for developers and other contractors from requests for proposals for utility-scale PV systems. All have minimum requirements for commercial general liability limits from \$1 million-\$2 million and commercial automobile liability limits from \$1 million-\$2 million. Most require workers' compensation limits ranging from $\$ 500,000$ to $\$ 1$ million. Other limits required include up to $\$ 1$ million for professional liability/errors-and-omissions coverage, umbrella or excess liability insurance increased limits to more than $\$ 25$ million, pollution liability limits of $\$ 5$ million, and a minimum $\$ 5$ million limit on cyber insurance for first-party damage occurring from a cyberrelated loss. 
Utility-scale PV project owners or operators should also maintain business interruption insurance for lost production and business income from a covered property loss when the system is not operational pending repairs. This can be critical to maintaining financing payments and other business operations after a major loss. These projects might also need mechanical and equipment breakdown insurance to extend business interruption coverage to these otherwise not covered causes. Other coverage that might be needed for businesses include cyber-risk insurance, executive risk coverage (also called directors' and officers' liability), and employers' liability, which protect against claims by employees. 
Table 4. Insurance Requirements from Requests for Proposals for Utility-Scale PV Systems

\begin{tabular}{|c|c|c|c|}
\hline $\begin{array}{l}\text { System } \\
\text { Categories } \\
\text { and Types }\end{array}$ & Developer's Insurance Re & uirements & \\
\hline \multirow{8}{*}{$\begin{array}{l}\text { Ground } \\
\text { mounted; } \\
\text { utility scale }\end{array}$} & Developer: & Design/engineering: & Construction: \\
\hline & $\begin{array}{l}\text { 1. Workers' compensation } \\
\text { and employers' liability }\end{array}$ & $\begin{array}{l}\text { 1. Workers' compensation } \\
\text { and employers' liability } \\
\text { (not less than } \$ 500,000 \text { ) }\end{array}$ & $\begin{array}{l}\text { 1. Workers' compensation } \\
\text { and employers' liability } \\
\text { (lot less than } \$ 1,000,000 \text { ) }\end{array}$ \\
\hline & $\begin{array}{l}\text { 2. Commercial general } \\
\text { liability (primary and } \\
\text { umbrella): not less than } \\
\$ 1,000,000\end{array}$ & $\begin{array}{l}\text { 2. Commercial general } \\
\text { liability (primary and } \\
\text { umbrella): not less than } \\
\$ 1,000,000\end{array}$ & $\begin{array}{l}\text { 2. Commercial general } \\
\text { liability (primary and } \\
\text { umbrella): not less than } \\
\$ 1,000,000\end{array}$ \\
\hline & $\begin{array}{l}\text { 3. Automobile liability } \\
\text { (primary and umbrella): } \\
\text { not less than } \$ 1,000,000\end{array}$ & $\begin{array}{l}\text { 3. Automobile liability } \\
\text { (primary and umbrella): not } \\
\text { less than } \$ 1,000,000\end{array}$ & $\begin{array}{l}\text { 3. Automobile liability } \\
\text { (primary and umbrella): not } \\
\text { less than } \$ 1,000,000\end{array}$ \\
\hline & $\begin{array}{l}\text { 4. Excess/umbrella: } \\
\text { not less than } \$ 2,000,000\end{array}$ & $\begin{array}{l}\text { 4. Excess/umbrella: not less } \\
\text { than } \$ 1,000,000\end{array}$ & $\begin{array}{l}\text { 4. Excess/umbrella: not } \\
\text { less than } \$ 5,000,000\end{array}$ \\
\hline & $\begin{array}{l}\text { 5. Professional liability: } \\
\text { not less than } \$ 1,000,000\end{array}$ & $\begin{array}{l}\text { 5. Professional liability: } \\
\text { not less than } \$ 2,000,000\end{array}$ & $\begin{array}{l}\text { 5. Builders risk/ } \\
\text { installation floater }\end{array}$ \\
\hline & $\begin{array}{l}\text { Developer may use a } \\
\text { combination of primary and } \\
\text { excess/umbrella } \\
\text { policy/policies to satisfy }\end{array}$ & $\begin{array}{l}\text { Design firm may use a } \\
\text { combination of primary and } \\
\text { excess/umbrella policies to } \\
\text { satisfy the limits of liability }\end{array}$ & $\begin{array}{l}\text { 6. Contractors' pollution } \\
\text { liability: not less than } \\
\$ 1,000,000\end{array}$ \\
\hline & $\begin{array}{l}\text { the limits of liability } \\
\text { required }\end{array}$ & & \\
\hline $\begin{array}{l}\text { Roof } \\
\text { mounted }\end{array}$ & \multicolumn{3}{|c|}{$\begin{array}{l}\text { 1. Commercial general liability: } \$ 1,000,000 \text { for each occurrence and } \$ 2,000,000 \text { in } \\
\text { aggregate }\end{array}$} \\
\hline (commercial) & \multicolumn{3}{|c|}{ 2. Workers' compensation: not less than $\$ 500,000$} \\
\hline $\begin{array}{l}\text { and ground } \\
\text { mounted }\end{array}$ & \multicolumn{3}{|c|}{ 3. Business automobile liability: not less than $\$ 1,000,000$} \\
\hline (utility scale) $^{\mathrm{b}}$ & \multicolumn{3}{|c|}{ 4. Professional liability: $\$ 1,000,000$} \\
\hline \multirow{5}{*}{$\begin{array}{l}\text { Utility scale } \\
120 \mathrm{MWac}^{\mathrm{C}}\end{array}$} & \multicolumn{3}{|c|}{ 1.Commercial general liability: $\$ 2,000,000$} \\
\hline & \multicolumn{3}{|c|}{$\begin{array}{l}\text { 2. Business automobile liability: a minimum single limit of } \$ 2,000,000 \text { per claim for bodily } \\
\text { injury and property damage }\end{array}$} \\
\hline & \multicolumn{3}{|c|}{ 3. Excess general liability policy-minimum limit of $\$ 25$ million } \\
\hline & \multicolumn{3}{|c|}{ 4. Pollution liability-minimum limit of $\$ 5$ million } \\
\hline & \multicolumn{3}{|c|}{$\begin{array}{l}\text { 5. Cyber insurance-minimum limit of } \$ 5 \text { million to cover } 1 \text { st party damage } \\
\text { related to a cyber-related loss }\end{array}$} \\
\hline
\end{tabular}

a Chicago Infrastructure Trust 2018

b City of South Portland 2019

${ }^{c}$ Avista 2020

Newer, innovative solar energy insurance products combine elements of insurance with financial hedging mechanisms. These include solar shortfall insurance, weather transfer risk, and 
equipment failure coverage. Solar shortfall coverage (also called energy production insurance) pays a percentage of the amount short of projected yields in case lower than normal solar radiation, unintentional errors in calculations of the projected performance, improper installation of the solar plant, or defect or underperformance of the solar installation results in actual power generation falling below a specified retention level (HSB 2020). Weather transfer risk coverage addresses the risk of not meeting a specified level of production from weather. Equipment failure insurance provides coverage for losses outside of the manufacturer's warranty and for construction defects. These coverages can be bundled - for example, the Solar Revenue Put by $\mathrm{kWh}$ Analytics is an all-risk coverage combining elements of solar shortfall, weather risk, equipment failure, and construction defect (Alternative Energy Stocks 2018). Because these types of coverage reduce risk and guarantee project cash flow, they are projected to increase project debt financing with "portfolios supported by the Solar Revenue Put reporting debt sizing increases of $10 \%$ on average" (kWh Analytics 2018). This can result in a lower debt coverage ratio, less equity financing, and lower interest rates that might more than offset any increased premium (National Renewable Energy Laboratory 2018).

Cyber risk is an emerging exposure for which new coverage is being designed. Although cyberattacks more often focus on traditional utility providers by attacking control and communications systems, potentially resulting in service disruption or ransomware attacks, utility-scale PV power providers also have exposures to such threats. "Conventional cyber insurance products in the market focus on data breaches relating to personal information while newer products cover owners and operators in any circumstance where the ability to generate power - and the associated revenue - is impacted by a cyberattack on proprietary or third-party IT or operational technology systems" (Pickerel 2018).

\subsection{Third Parties}

\subsubsection{Consultants, Designers, Engineers, and Installers}

Firms designing, manufacturing, selling, engineering, or installing PV systems will need to maintain at least the coverage and limits required by the commercial entities they serve. These firms should ensure that their commercial general liability insurance includes coverage for claims made against the business and its employees from losses resulting from products and completed operations. Designers, consultants, engineers, and installers should also carry professional liability/errors-and-omissions insurance. Installers should ensure that coverage is in place for property or equipment in transit and for inventories of materials not yet installed, and they should ensure that they have adequate limits of general liability for any damage to others' property during installation as well as theft coverage for materials used for installations. Table 3 and Table 4 include examples of insurance requirements for these entities submitting proposals for commercial and PV-scale systems.

\subsubsection{Other Third Parties}

Insurance exposures vary as widely as the structures of property ownership, system management, and legal responsibility created through leases and other contracts. For example, a PV system developer might not own the property on which a system will be housed that they are responsible for developing, operating, and/or maintaining. The developer needs to work closely with the property owner and any other key parties to coordinate the risk management plan. Contracts need 
be scrutinized by all parties in the risk management process to ensure clarity and agreement on who is responsible for which exposures to avoid gaps or unnecessary duplication in coverage. It is important to have expert risk management advice as projects are being structured and to schedule annual reviews to ensure that no changes have taken place that could require adaptation in another party's risk management plan.

Similarly, a building owner leasing to an operation (or resident) that installs a rooftop PV system will need to ensure that their insurance coverage considers these exposures. Even homeowners who might contract with a third party to install rooftop solar on their home need to carefully review contracts to ascertain who owns the equipment and who is responsible for maintaining which types of insurance coverage, and they need to understand who is responsible for ongoing system maintenance or any other damage that could occur to the system. If the homeowner does not take ownership of the equipment (for example, under a lease arrangement), damage to the property might not be covered. Any special situations such as these should be discussed with the insurance agent or broker to confirm that coverage is in place for any potential losses. 


\section{Insurance Claims}

Insurance coverage is purchased for the security of knowing that if or when a loss occurs, financial consequences are covered. Whether for a homeowner, small commercial business, large commercial business, utility-scale insured, or a third party, claims handling and claims payment are the reasons for the insurance industry. It is as important to be prepared for the potential eventuality of a loss as it is to negotiate good insurance coverage terms.

Although the insurance agent or broker and the insurance company will maintain copies of coverage forms, it is a good idea to maintain extra copies of all insurance papers as well as an inventory of covered property and values away from the insured location. In case of a total onsite loss, this ensures that records are readily accessible. Insurance records should be maintained not only for the current period but also for past periods. This can be important even for very long periods of time because - especially for general liability - the insurance coverage in place at the time of an occurrence or accident governs the terms of payment of any claims. For example, for bodily injury coverage, there can be a long latency period between the time of injury and the realization of the actual loss or establishment of the cause of loss.

Insurance policies specify actions to be taken when a loss occurs or there is notification of a claim against the insured. Notification of the insurance company will begin any claims process. It is important to protect any property from further loss, and typically property insurance policies cover the costs of protecting property from additional losses. It is also very important to maintain detailed records of pre-loss property, business receipts, and expenses and records of any extra expense, lost business income, and repair costs.

Insurance companies claims handlers will guide the insured through the claims process. For many liability claims, insurance companies might also provide legal representation —or, at a minimum, because most liability policies provide for legal costs, they will require close coordination with legal counsel. The state insurance commissioner's office can be contacted in case of a dispute with an insurance company over their handling, denial, or payment of a claim or any other insurance practice. 


\section{Cost of Providing Insurance}

Insurance costs are determined based on a rate and the insured value of the system. The rate is established based on the type of system (construction); location (in a populated area or remote); protections in place (security fence, alarms, etc.), and exposure (vulnerability to perils such as hurricanes or hail). In theory, rates should decrease over time as the technology improves, insurers become more familiar with losses, and risk management improves ways to reduce risk and mitigate losses; however, recent storms and wildfires, unprecedented in severity, could push premiums higher and/or affect the availability of specific coverages.

As a relatively new asset class, during the last 10 years, reported insurance premiums on PV systems have varied substantially. In 2010, the National Renewable Energy Laboratory reported insurance premiums of approximately $0.25 \%-0.5 \%$ of the total installed cost of a project depending on the geographic location of the installation (Speer, Mendelsohn, and Cory 2010). At that time, the average cost of a PV system ranged from $\$ 4,000 / \mathrm{kw}-\$ 6,000 / \mathrm{kW}$, converting to approximately $\$ 10-\$ 30 / \mathrm{kW} /$ year, making insurance one of the major expenses in operating a solar plant. Later, for a PV operation-and-maintenance cost model, the National Renewable Energy Laboratory reported insurance costs of $0.10 \%$ of installed cost, or on the order of $\$ 2 / \mathrm{kW} /$ year for a large plant, based on industry input collected in 2017 (Walker et al. 2020). A survey of PV operators by Lawrence Berkeley National Laboratory in 2019 reported insurance costs of $\$ 0.90 / \mathrm{kW} /$ year (Wiser, Bolinger, and Seel 2020). The website Solar Insure reports that property insurance premiums range from $0.15 \%-0.30 \%$ of installed cost, or approximately $\$ 4 / \mathrm{kW} /$ year-\$10/kW/year (Solar Insure 2020). Although these data are anecdotal rather than complete, they do indicate that insurance costs can be a significant component of PV system operating costs and the cost of delivered energy. Solar developers that agree to a fixed power purchase price $(\$ / \mathrm{kWh}$ delivered) during a long period (e.g., 20 years) should consider that insurance costs could increase within the term of the power purchase agreement.

Both providers and buyers of insurance can help manage insurance costs by doing the following:

1. Engage knowledgeable risk management professionals to design a risk management approach that optimizes your use of insurance and to help procure the right coverage at the best price. The quality and financial stability of your carrier are important factors in overall costs. The lowest premium is not always the lowest resulting total cost.

2. Conduct an annual risk management and insurance review. Work with your current and potential new agents or brokers to identify emerging or changed exposures, check the market for new competitors, and take advantage of products and service innovations or improved rate structures.

3. Adopt practices that can reduce loss exposure, such as increased security measures. Consider factors an underwriter will use in setting premiums. Take advantage of any broker or insurance carriers' risk management or loss engineering expertise well in advance of contract renewal.

4. As systems age, revisit coverage limits to factor in projected decreases in PV module replacement costs. This could enable you to reduce overall limits and associated premiums. 
5. Consider opportunities to bundle multiple smaller systems in a fleet or under common ownership to negotiate better rates. Look at ways to retain and manage smaller losses across your fleet.

6. Investigate the effect of retaining smaller losses and using higher deductibles, using insurance for unexpected or unaffordable large or catastrophic losses rather than affordable repairs following normal incidents. 


\section{Conclusion}

Premiums for insurance coverage related to residential, commercial, and utility-scale PV systems are driven by actual loss experience, affecting changes in rates and the availability of coverage for PV systems. The analysis of insurance claims with losses to PV equipment from 2014-2019 shows that although the causes of most claims and the largest claim sizes were from hail, wind, fire, and lightning, losses arose from a broad range of perils. PV systems in different geographic locations are exposed to significantly different perils, which drives differences in insurance costs. As the PV industry matures, PV systems will become more robust in the face of expected perils, loss experience will become more stable and certain, and insurance costs will likely stabilize. PV plant operators can optimize the management of risk and the cost of insurance through design, construction, and O\&M measures that reduce risk and through careful selection of coverage and deductibles.

The insurance industry continues to design creative solutions to long-standing and well-known as well as new and emerging threats and exposures for PV system owners, including homeowners, commercial enterprises, and utility-scale PV power generators as well as the third parties that develop, design, and install these systems. The insurance industry offers products customized for the concerns of insured PV plants to manage a wide range of risks of property, liability, and performance. Working with experienced and knowledgeable risk managers, brokers, and agents can help buyers of insurance for PV plants ensure cost-effective coverage tailored to the specific needs of the insureds. 


\section{References}

Alternative Energy Stocks. 2018. "How Weather Risk Transfer Can Help Wind \& Solar Development." June 27, 2018. http://altenergystocks.com/archives/2018/06/how-weather-risktransfer-can-help-wind-solar-development.

Anne Arundel County. 2015. "Request for Proposals, RFP No. 16-002R, Power Purchase Agreements for Solar Photovoltaic Systems." Annapolis, MD. http://www.bidnet.com/bneattachments?/378500294.pdf.

Avista. 2020. "Request for Proposals. Renewable Energy. Approximately 120 Average Megawatts." Avista\%202020\%20Renewables\%20RFP\%20Final.pdf. Spokane, WA.

Bache, Larry. 2011. "What Are Coinsurance Clauses and Do Courts Enforce Them?" Property Insurance Coverage Law Blog, September 29, 2011. https://www.propertyinsurancecoveragelaw.com/2011/09/articles/insurance/what-arecoinsurance-clauses-and-do-courts-enforce-them/.

Buncombe County, North Carolina. 2019. "Request for Proposals, Buncombe County, North Carolina, Renewable Energy Installation and Financing." Asheville, NC. https://www.buncombecounty.org/common/Commissioners/20191105/Public\%20Facility\%20So lar_RFP\%20DRAFT.pdf.

Cape \& Vineyard Electric Cooperative, Inc. 2017. "Request for Proposal for Rooftop Solar Photovoltaic Energy Facilities at Five Municipal Properties by the Cape and Vineyard Electric Cooperative." http://www.cvecinc.org/library/2017/05/07/CVEC-Roof-Mounts-RFP-9-1917.pdf. (accessed September 2020)

Chicago Infrastructure Trust. 2018. "Request for Proposals (RFP) to Design, Build, Finance, Own, Operate, and Maintain Ground-Mounted Solar Photovoltaic Electric Generation Systems on City of Chicago Owned Vacant Land." Chicago, IL. http://chicagoinfrastructure.org/wpcontent/uploads/2018/09/Chicago-Solar-RFP 20181001.pdf.

City of Concord, New Hampshire. 2019. "Purchasing Division, Ground-Mounted Solar Photovoltaic Systems on City-Owned Parcels." https://www.concordnh.gov/DocumentCenter/View/14143/Concord--RFP-01-20-Solar-PVFinal-19-0809v3?bidId $=$.

City of South Portland. 2019. "Request for Proposals for Solar Photovoltaic Projects." https://www.bowdoinham.com/sites/default/files/towndocument/Solar\%20RFP\%20December\%202019.pdf.

HSB Canada. 2020. "Why do I need equipment breakdown coverage for my solar PV system"? Knowledge Centre. https://www.munichre.com/hsbcanada/en/knowledge-centre/miniwebinars/why-do-i-need-equipment-breakdown-coverage-for-my-solar-pvsystem.html\#1735695378. 
HSB. 2020. "Energy Shortfall Insurance." Products.

https://www.munichre.com/hsb/en/products/commercial-lines-agents-and-brokers/energyinsurance/energy-shortfall-insurance.html.

Insurance Information Institute. 2020a. "How to Assess the Financial Strength of an Insurance Company." Accessed December 2020. https://www.iii.org/article/how-to-assess-the-financialstrength-of-an-insurance-company.

Insurance Information Institute. 2020b. “Insurance 101.” Accessed September 2020. https://www.iii.org/article/insurance-101.

International Risk Management Institute, Inc. 2020. "Exposure.” Glossary. Accessed November 2020. https://www.irmi.com/term/insurance-definitions/exposure.

Kaskaskia College. 2020. "Request for Proposals, Agriculture Education Center Solar PV System." Centralia, IL.

https://illinoissolar.org/resources/Documents/Kaskaskia\%20College\%20Ag\%20Center\%20Solar \%20RFP\%206-23-2020.pdf.

kWh Analytics. 2018. "kWh Analytics Closes Solar Revenue Put for 35 MW of Solar Power Projects with IGS Solar, Ares Management, ING, and Swiss Re." Accessed September 4, 2020. https://www.kwhanalytics.com/blog-archive/kwh-analytics-closes-solar-revenue-put-for-35-mwof-solar-power-projects-with-igs-solar-ares-management-ing-swiss-re.

Loudoun County Public Schools. 2019. "RFP \#R20242, Solar Power Purchase Agreement Services." Ashburn, VA.

https://www.lcps.org/site/handlers/filedownload.ashx?moduleinstanceid=11092\&dataid=339732 \&FileName=RFP_R20242\%20Solar $\% 20$ Power $\% 20$ Purchase $\% 20$ Agreement $\% 20$ Services $\% 20 \mathrm{du}$ e \%2009.19.19\%20at\%202pm.pdf.

National Renewable Energy Laboratory, Sandia National Laboratory, SunSpec Alliance, and the SunShot National Laboratory Multiyear Partnership (SuNLaMP) PV O\&M Best Practices Working Group. 2018. Best Practices for Operation and Maintenance of Photovoltaic and Energy Storage Systems; 3rd Edition (NREL/TP-7A40-73822). Golden, CO: National Renewable Energy Laboratory. https://www.nrel.gov/docs/fy19osti/73822.pdf.

Pickerel, Kelly. 2018. "GCube Launches New Cyber Risk Insurance Policy for Renewable Energy Asset Owners." Solar Power World, September 6, 2018. Accessed September 4, 2020. https://www.solarpowerworldonline.com/2018/09/gcube-launches-new-cyber-risk-insurancepolicy-for-renewable-energy-asset-owners/.

Solar Insure. 2020. Accessed October 1, 2020. https://www.solarinsure.com/for-solardevelopers-how-solar-property-insurance-is-priced.

Solar Workgroup of Southwest Virginia. 2019. "Solar Services Request for Proposals, Solar Workgroup of Southwest Virginia, 2019 Group Solicitation." https://swvasolar.org/wpcontent/uploads/2019/04/SWVA-April-2019-Solar-RFP.pdf. 
Speer, Bethany, Michael Mendelsohn, and Karlynn Cory 2010. Insuring Solar Photovoltaics: Challenges and Possible Solutions (NREL/TP-6A2-46932). Golden, CO.

https://www.nrel.gov/docs/fy10osti/46932.pdf.

Walker, Andy, Eric Lockhart, Jal Desai, Kristen Ardani, Geoff Klise, Olga Lavrova, Tom Tansy, Jessie Deot, Bob Fox, and Anil Pochiraju. 2020. Model of Operation-and-Maintenance Costs for Photovoltaic Systems (NREL/TP-5C00-74840). Golden, CO: National Renewable Energy Laboratory. https://www.nrel.gov/docs/fy20osti/74840.pdf.

Wiser, Ryan H., Mark Bolinger, and Joachim Seel. 2020. Benchmarking Utility-Scale PV Operational Expenses and Project Lifetimes: Results from a Survey of U.S. Solar Industry Professionals. Berkeley, CA: Lawrence Berkeley National Laboratory. doi:10.2172/1631678. https://www.osti.gov/servlets/purl/1631678. 


\section{A.1 Insurance Checklist}

For residential photovoltaic (PV) systems, homeowners' insurance extends property coverage to the PV array and liability coverage to bodily injury to others or damage to the property of others that occurs as a result of the system. For small commercial PV systems, typically the business owners' policy includes property and general liability coverage similar to that of a residential homeowner. For large commercial insureds with PV system generation, for stand-alone commercial PV systems, or for utility or distributed-generation PV systems, the following list includes possible insurance coverage types to consider. ${ }^{5}$ In this growing and emerging market, however, a knowledgeable insurance agent or broker should be consulted for information on new and changing coverage.

- Property insurance: covers the value of owned buildings, equipment, and improvements to the property from a set of named perils (such as fire, hail, or wind) or on an all-risk basis (which covers all causes of loss unless specifically excluded)

- Commercial general liability insurance: covers liability for loss caused by actions of owner or contractors or losses arising from the ownership or operation of a property. Includes coverage for employees or independent contractors for property damage or bodily injury arising from the premises and operations or from products and completed operations. Might include personal injury, broad form property damage, and blanket contractual liability. Coverage includes settlement and legal costs.

- Inland marine insurance: insures against loss of owned property or equipment not on the insured premises. Inland coverage is often included in a property insurance policy.

- Worker's compensation: covers bodily injury to employees while engaged in employment-related activities. Limits are typically set based on statute.

- Professional liability/errors-and-omissions insurance: insures against liability from errors and omissions in providing a broad range of professional services - for example, by architects, engineers, and PV system installers. Also includes executive liability insurance (also called directors' and officers' liability) coverage for company officers and directors for their actions in those roles.

- Commercial vehicle insurance: insures owned and rented vehicles or personal vehicles used for company business. Includes damage to the vehicles as well as liability for injury to others from operation of the vehicles.

- Warranty insurance: includes an equipment warranty issued by the manufacturer but backed by an insurance company in case the manufacturer company goes out of business. Serial defects of a manufactured product are typically covered under the manufacturer's products and completed operations insurance coverage.

- Business interruption insurance: covers lost production, business income, or extra expenses resulting from downtime caused by the covered event. This can be important in power purchase agreements where revenue is essential for debt service and operationand-maintenance expenditures. Property insurance can be extended to include business interruption insurance, which provides coverage for lost income and extra expenses following a physical loss. This can also apply to contingent losses, such as a loss to

\footnotetext{
5 This checklist is an update and expansion from that first published in https://www.nrel.gov/docs/fy19osti/73822.pdf.
} 
inventory or spoilage from a disruption. For even small property losses, the loss of business income from a disruption in operations can be many times the cost of a property claim. Also, if the business involves refrigeration (e.g., food, laboratories), spoilage coverage can be important, especially in combination with coverage for disruptions in power supply.

- Solar Revenue Put: combines elements of solar shortfall insurance (also called energy production insurance), which insures against the PV system producing at a lower output than specified; weather transfer risk, which ensures a specified level of production resulting from weather; and mechanical breakdown or equipment failure insurance, which covers losses outside of manufacturer's warranty coverage as well as coverage for construction defects.

- Environmental liability/pollution coverage: indemnifies system owners of the risk of either environmental damage done by their development or preexisting damage on the development site (Speer, Mendelsohn, and Speer 2010).

- Employers' liability insurance: covers claims brought by employees against the employer for employment practices.

- Cyber risk insurance: covers data breaches relating to personal information as well as related losses from the loss of the ability to generate power-and the associated revenue - from a cyberattack on proprietary or third-party information technology or operational technology systems. Coverage can also be extended to include a cyberattack on assets not actually owned by the insured, such as damage to a third-party substation or transmission infrastructure that prevents the export of power (Pickerel 2018). 